Jurnal Tanah dan Sumberdaya Lahan Vol 7 No 2 : 291-297, 2020

e-ISSN:2549-9793, doi: 10.21776/ub.jts1.2020.007.2.13

\title{
POTENSI TANAMAN RAMI (Boehmeria nivea) UNTUK FITOREMEDIASI TANAH TERCEMAR TEMBAGA
}

\section{The Potential of Rami (Boehmeria nivea) for Phytoremediation of Copper Contaminated Soil}

\author{
Nina Dwi Lestari*, Naufal Rizka Pratama \\ Jurusan Tanah, Fakultas Pertanian, Universitas Brawijaya, Jl. Veteran no 1, Malang 65145 \\ *Penulis korespondensi: nd_lestari@yahoo.com
}

\begin{abstract}
One of the heavy metals that most contaminates the environment and soil is copper $(\mathrm{Cu})$ that mostly comes from the activities of electroplating industries. This study aimed to identify the ability of Boebmeria nivea in absorbing $\mathrm{Cu}$ absorption from planting medium containing $\mathrm{Cu}$. The Boebmeria nivea plant was grown on soil contaminated with six $\mathrm{CuSO}_{4}$ concentration levels, i.e. $0 \mathrm{ppm} \mathrm{Cu}(\mathrm{P} 0), 10$ ppm Cu (P1), 20 ppm Cu (P2), 30 ppm Cu (P3), 40 ppm Cu (P4), and $50 \mathrm{ppm} \mathrm{Cu} \mathrm{(P5).} \mathrm{The} \mathrm{results}$ showed that Boehmeria nivea plant could absorb $\mathrm{Cu}$ and survive in the $\mathrm{Cu}$ levels of $25-125 \mathrm{ppm}$ in the soil. The Bioremediation Index indicated that Boehmeria nivea could reduce copper in the soil up to more than $50 \%$. The mechanism of phytoremediation was categorized into phytostabilization, since the result of all treatments showed the value of translocation factor (TF) of less than 1 . The presence of $\mathrm{Cu}$ in the soil affected plant height and leaf number of the plant Boebmeria nivea. However, on the actual condition, Boehmeria nivea did not show any symptom of $\mathrm{Cu}$ toxicity.
\end{abstract}

Keywords: absorption, copper, heavy metal, phytoremediation

\section{Pendahuluan}

Aktivitas manusia dalam bidang industri semakin berkembang seiring berjalannya waktu. Industri semakin maju dan semakin banyak alih fungsi lahan yang digunakan untuk pengembangan sektor industri seperti industri tekstil, elektroplanting, pupuk kimia dan pestisida kimia. Luaran dari kegiatan industri yang dihasilkan berupa limbah yang menyebabkan lingkungan menjadi tercemar limbah yang dihasilkan, limbah ini dapat dengan mudah masuk kedalam strata lingkungan salah satunya masuk ke dalam tanah yang digunakan untuk area pertanian sehingga menyebabkan pencemaran menjadi suatu permasalahan yang serius yang mencemari lingkungan terutama tanah (Palar, 2008).

Salah satu bahan pencemar lingkungan yang banyak menarik perhatian adalah pencemaran oleh kontaminasi logam berat. Kontaminasi oleh logam berat menjadi perhatian serius karena menimbulkan kontaminasi pada tanah melalui pembuangan secara langsung baik, limbah padat maupun limbah cair.

Tanah merupakan salah satu komponen yang menjadi sasaran pencemaran, bila tanah yang digunakan sebagai kegiatan pertanian tercemar logam berat maka logam berat akan masuk ke dalam rantai makanan yang akhirnya menuju kepada manusia sebagai konsumen sehingga menimbulkan berbagai macam penyakit pada manusia khususnya ganguan pada system syaraf (Sudarmaji, 2006). Salah satu logam berat yang banyak mencemari lingkungan khusunya di tanah adalah tembaga $(\mathrm{Cu})$, logam berat tembaga dapat masuk ke dalam strata lingkungan yang diduga paling banyak adalah dari kegiatan perindustrian, kegiatan rumah tangga dan dari pembakaran serta mobilitas bahan bakar serta limbah dari industri elektroplating yang merupakan salah satu industri yang menghasilkan limbah cair (Palar, 
2008). Salah satu upaya mengurangi konsentrasi pencemaran logam berat tembaga $(\mathrm{Cu})$ untuk membenahi tanah adalah fitoremediasi. Fitoremediasi adalah suatu sistem tanaman tertentu yang dapat melakukan kerja sama dengan mikroorganisme dalam media (tanah, koral, dan air), dapat mengubah zat kontaminan (pencemar/polutan) menjadi kurang atau tidak berbahaya (Greipsson, 2011).

Tanaman fitoremediator yang dapat digunakan adalah tanaman rami (Boebmeria nivea) yang merupakan tanaman tahunan dan memiliki potensi yang cukup tinggi untuk dikembangkan, tanaman rami dapat tumbuh secara liar serta dikenal mampu menyerap toksik tertentu seperti tembaga $(\mathrm{Cu})$. Tanaman rami berpotensi untuk dikembangkan menjadi tanaman fitoremediator untuk mengurangi atau menetralisir pencemaran logam-logam berat khususnya logam tembaga $(\mathrm{Cu})$, serta perlunya diketahui besar penyerapan logam yang terakumulasi sehingga mengetahui baik atau tidaknya tanaman rami dapat dijadikan sebagai tanaman hiperakumulator.

Penelitian fitoremediasi menggunakan tanaman rami ini bertujuan untuk mengetahui kemampuan tanaman dalam penyerapan logam berat tembaga $(\mathrm{Cu})$ pada konsentrasi tertentu, mengetahui mekanisme tanaman rami dalam penyerapan logam berat tembaga $(\mathrm{Cu})$ dan mengetahui pengaruh pencemaran logam berat tembaga $(\mathrm{Cu})$ terhadap pertumbuhan tanaman rami.

\section{Bahan dan Metode}

\section{Lokasi penelitian}

Penelitian ini dilaksanakan pada 11 Maret hingga 1 Juni 2019 di Greenhouse Kebun Percobaan Sekolah Tinggi Penyuluhan Pertanian (STPP) Malang. Analisis logam tembaga (Cu) yang dilakukan di Laboratorium Kimia Fakultas Matematika dan Ilmu Pengetahuan Alam Universitas Negeri Malang.

\section{Alat dan bahan}

Alat-alat yang digunakan dalam penelitian ini terbagi menjadi 2 bagian yaitu alat di lapang dan di laboratorium. Alat dan bahan yang digunakan pada saat di lapangan yaitu cangkul, pot, timbangan digital, gelas ukur, gelas plastik, ember, pipa plastik, papan alfaboard. Sedangkan bahan-bahan yang digunakan adalah bahan pencemar berupa logam tembaga $(\mathrm{Cu})$ dalam bentuk padatan kristal $\mathrm{CuSO}_{4}$ rhizome tanaman rami sebagai tanaman fitoremediator, tanah untuk media tanam, aquades sebagai pelarut bahan pencemar serta pupuk kandang dan cocopeat sebagai pupuk starter pada awal penanaman. Alat dan bahan di laboratorim adalah timbangan digital, spatula, botol timbangan, kertas saring, corong, labu Erlenmeyer $25 \mathrm{ml}$, gelas ukur, pipet skala, wadah plastik, alat Spektrofotometer Serapan Atom, sampel tanaman rami dan aquades.

\section{Rancangan penelitian}

Penelitian ini dilaksanakan pada percobaan dalam pot yang dilakukan di greenhouse dengan metode Rancangan Acak Lengkap (RAL) Perlakuan terdiri dari 6 perlakuan (Tabel 1) dengan 4 kali ulangan sehingga didapat 24 unit sampel penelitian.

Tabel 1. Perlakuan penelitian.

\begin{tabular}{|c|c|c|}
\hline No & Kode & Perlakuan \\
\hline 1 & P0 & Tanpa perlakuan tembaga \\
\hline 2 & P1 & $\begin{array}{l}\text { Tembaga dengan konsentrasi } \\
10 \text { ppm }\end{array}$ \\
\hline 3 & P2 & $\begin{array}{l}\text { Tembaga dengan konsentrasi } \\
20 \text { ppm }\end{array}$ \\
\hline 4 & P3 & $\begin{array}{l}\text { Tembaga dengan konsentrasi } \\
30 \text { ppm }\end{array}$ \\
\hline 5 & P4 & $\begin{array}{l}\text { Tembaga dengan konsentrasi } \\
40 \text { ppm }\end{array}$ \\
\hline 6 & P5 & $\begin{array}{l}\text { Tembaga dengan konsentrasi } \\
50 \text { ppm }\end{array}$ \\
\hline
\end{tabular}

\section{Pelaksaan penelitian}

Persiapan media tanam yang digunakan dalam penelitian ini adalah tanah dan pupuk kandang yang dicampur cocopeat dengan dosis tanah 10 $\mathrm{kg}$ dan pupuk kandang $50 \mathrm{~g}$. Tanah yang digunakan sebagai media tanam diambil di Kebun Percobaan Sekolah Tinggi Penyuluhan Pertanian (STPP). Tanah yang digunakan di ambil pada bagia Sebelum dilakukan penanaman tanaman rami terlebih dahulu dilakukan persiapan media tanam dengan mencampurkan tanah dan pupuk kandang yang sudah tercampur dengan cocopeat. Kemudian penanaman tanaman rami dalam bentuk rhizome yang 
diperoleh dari BALITTAS. Penanaman rhizome dilakukan sebanyak 1 rhizome per 1 pot tanam berukuran $20 \mathrm{~cm} \times 20 \mathrm{~cm}$ yang terisi $10 \mathrm{~kg}$ tanah dengan jarak tanam $50 \mathrm{~cm} \times 80 \mathrm{~cm}$. Top Soil (yakni pada ke dalaman $0-20 \mathrm{~cm}$ ). Pemeliharaan dilakukan setiap hari dengan tujuan untuk memberikan kondisi yang menguntungkan bagi pertumbuhan tanaman. Aplikasi bahan pencemar berupa $\mathrm{CuSO}_{4}$ sesuai dosis yang diberikan yakni, 0 ppm, 25 ppm, 50 ppm, 75 ppm, $100 \mathrm{ppm}$ dan $125 \mathrm{ppm}$. Kemudian dilarutkan dengan aquades sebanyak 1 liter dan dikocok. Setelah larutan tercampur kemudian langsung di aplikasikan ke tanaman rami pada masing-masing perlakuan dan ulangan. Parameter yang diamati berupa tinggi tanaman dan jumlah daun yang dilakukan setiap 14 HST hingga panen. Setelah masuk kedalam 81 hst dilakukan analisis berupa sampel tanah dan tanaman yaitu akar dan tajuk.

\section{Analisis data}

Berdasarkan hasil pengujian laboratorium, akan didapatkan data primer berupa besarnya kadar $\mathrm{Cu}$ pada tanah dan tanaman. Dari hasil pengujian tersebut akan dilakukan analisis ragam (ANOVA). Data diolah dengan menggunakan aplikasi GENSTAT. Apabila hasil analisis menunjukkan adanya perbedaan antar perlakuan maka dilanjutkan dengan dengan uji Duncan Multiple Ring Test pada taraf signifikan 5\%.

\section{Hasil dan Pembahasan \\ pH tanah}

Berdasarkan hasil pengukuran $\mathrm{pH}$ yang dilakukan didapatkan hasil yang disajikan di dalam grafik pada Gambar 1.

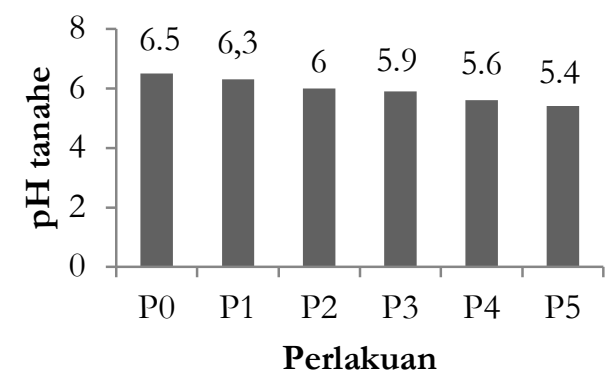

Gambar 1. Pengaruh konsentrasi $\mathrm{Cu}$ terhadap $\mathrm{pH}$ tanah.
Aplikasi bahan pencemar logam berat tembaga $(\mathrm{Cu})$ memiliki pengaruh dengan hasil semakin tinggi kadar logam berat $\mathrm{Cu}$ di dalam tanah maka semakin kecil juga nilai $\mathrm{pH}$ yang terdapat di dalam tanah. Menurut Abror et al. (2013) bahwa nilai $\mathrm{pH}$ dan keberadaan logam berat yang ada di dalam tanah tidak berbanding lurus, dimana peningkatan $\mathrm{pH}$ diikuti oleh penurunan kandungan logam berat yang ada di dalam tanah dan berarti bahwa kandungan logam tembaga $(\mathrm{Cu})$ di dalam tanah mempengaruhi nilai $\mathrm{pH}$.

\section{Pertumbuhan tanaman rami}

Tanaman rami yang diberikan perlakuan berupa cemaran logam berat tembaga $(\mathrm{Cu})$ mempengaruhi pertumbuhan dari tanaman rami yang berpengaruh pada parameter yang diamati yaitu tinggi tanaman dan jumlah daun. Tanaman rami ini menyerap cemaran logam berat tembaga $(\mathrm{Cu})$ melalui akar tanaman dan di translokasikan kebagian batang dan daun sehingga akan mempengaruhi dari tinggi tanaman dan jumlah daun. Hasil dari pertumbuhan tinggi tanaman dan jumah daun disajikan dalam Tabel 2 dan Tabel 3.

Berdasarkan hasil dari analisis ragam yang didapat untuk parameter pengamatan tinggi tanaman dan jumlah daun tanaman rami akibat pengaplikasian logam berat tembaga $(\mathrm{Cu})$ menunjukkan hasil yang berpengaruh nyata, kedua parameter ini menunjukan bahwa adanya cemaran logam dapat mempengaruhi pertumbuhan dari tanaman. Menurut Hardiani (2009), kadar $\mathrm{Cu}$ yang berlebihan pada media tanam dapat menghambat pertumbuhan tanaman sehingga tanaman tidak mampu tumbuh besar. Tanaman rami dapat tumbuh dengan baik namun kurang optimal karena adanya logam berat tembaga $(\mathrm{Cu})$ pada tanah yang mempengaruhi pertumbuhan dari tanaman rami. Tinggi tanaman dan jumlah daun tanaman rami pada kontrol P0 memiliki persentase yang lebih tinggi dibandingkan perlakuan yang diberikan cemaran logam tembaga $(\mathrm{Cu})$ lainnya. $\mathrm{Hal}$ ini disebabkan oleh tingginya kandungan logam berat termasuk tembaga $(\mathrm{Cu})$ yang membuat aktivitas enzim menjadi terhambat dan menggangu ketersediaan berbagai unsur hara sehingga menyebabkan pertumbuhan tanaman rami dengan cemaran logam tembaga menjadi terganggu (Handayanto et al., 2017). Kation $\mathrm{Cu}$ yang terserap oleh akar masuk ke 
dalam tanaman akan menjadi inhibitor pembentukan enzim kemudian akan menghambat proses metabolime tanaman, yang meliputi proses respirasi yang nantinya akan menghasilkan ATP yang digunakan untuk fotosintesis, kemudian hasil fotosintesis akan digunakan dan diedarkan untuk pembelahan sel (tinggi tanaman, jumlah daun dan biomassa tanaman) dan reproduksi akan terganggu. Apabila ini dilakukan terus menerus dalam jangka waktu panjang akan menyebabkan menurunnya kualitas pertumbuhan tanaman rami dan mengakibatkan pertumbuhan tanaman terganggu (Amelia et al., 2008). Pada kondisi di lapang tanaman rami tidak mengalami gejala keracunan atau kerusakan pada organ tanaman, sehingga diduga tanaman rami ini mampu mentolerir logam berat tembaga $(\mathrm{Cu})$ dalam jumlah yang besar, bahkan dalam jumlah yang mendekati batas kritis pada tanah dan tanaman yaitu 100 ppm dan 125 ppm.

Menurut Priyanto dan Prayitno (2007) logam berat yang masuk ke dalam tanaman akan berikatan dengan unsur hara lain dan mengalami imbobilisasi ke bagian tanaman tertentu dan tidak dapat diedarkan ke seluruh tanaman karena telah mengalami proses detoksifikasi (penimbunan pada organ tertentu) sehingga tanaman masih dapat tumbuh dan unsur hara yang diperlukan tanaman masih mampu untuk mensuplai pertumbuhan tanaman meskipun tercemar logam berat $\mathrm{Cu}$.

Tabel 2. Tinggi tanaman rami.

\begin{tabular}{ccccccc}
\hline \multirow{2}{*}{ Perlakuan } & \multicolumn{7}{c}{ Tinggi Tanaman (cm) } \\
\cline { 2 - 7 } & 14 HST & 28 HST & 42 HST & 56 HST & 70 HST & 81 HST \\
\hline P0 & $9,8 \mathrm{ab}$ & $25,8 \mathrm{~b}$ & $53,30 \mathrm{~b}$ & $104,5 \mathrm{e}$ & $117,0 \mathrm{~d}$ & $125,8 \mathrm{e}$ \\
P1 & $7,0 \mathrm{a}$ & $23,3 \mathrm{~b}$ & $56,00 \mathrm{~b}$ & $97,8 \mathrm{~d}$ & $106,5 \mathrm{c}$ & $110,3 \mathrm{~d}$ \\
P2 & $13,0 \mathrm{~b}$ & $26,0 \mathrm{~b}$ & $63,50 \mathrm{c}$ & $97,3 \mathrm{~cd}$ & $106,8 \mathrm{c}$ & $108,3 \mathrm{~cd}$ \\
P3 & $9,9 \mathrm{ab}$ & $24,0 \mathrm{~b}$ & $53,75 \mathrm{~b}$ & $90,3 \mathrm{~b}$ & $102,8 \mathrm{bc}$ & $103,3 \mathrm{bc}$ \\
P4 & $12,3 \mathrm{~b}$ & $17,8 \mathrm{a}$ & $33,25 \mathrm{a}$ & $79,0 \mathrm{a}$ & $94,8 \mathrm{a}$ & $96,0 \mathrm{a}$ \\
P5 & $5,8 \mathrm{a}$ & $35,8 \mathrm{c}$ & $68,00 \mathrm{c}$ & $93,0 \mathrm{bc}$ & $98,0 \mathrm{ab}$ & $99,5 \mathrm{ab}$ \\
\hline
\end{tabular}

Keterangan : Hari Setelah Tanam (HST) P0 adalah aplikasi Cu dengan dosis 0 ppm, P1 aplikasi Cu dosis 25 ppm, P2 aplikasi Cu dosis 50 ppm, P3 aplikasi Cu dosis 75 ppm, P4 aplikasi Cu dosis 100 ppm dan P5 aplikasi $\mathrm{Cu}$ dosis $125 \mathrm{ppm}$

Tabel 3. Jumlah daun rami.

\begin{tabular}{ccccccc}
\hline Perlakuan & \multicolumn{7}{c}{ Jumlah Daun (helai) } \\
\cline { 2 - 7 } & $\mathbf{1 4}$ HST & 28 HST & 42 HST & 56 HST & 70 HST & 81 HST \\
\hline P0 & 11 & $24 \mathrm{c}$ & $32 \mathrm{ab}$ & $44 \mathrm{ab}$ & $70 \mathrm{bc}$ & $87 \mathrm{~b}$ \\
P1 & 12 & $20 \mathrm{~b}$ & $29 \mathrm{a}$ & $49 \mathrm{~b}$ & $74 \mathrm{c}$ & $75 \mathrm{a}$ \\
P2 & 14 & $16 \mathrm{a}$ & $36 \mathrm{bc}$ & $57 \mathrm{c}$ & $64 \mathrm{a}$ & $76 \mathrm{a}$ \\
P3 & 12 & $20 \mathrm{~b}$ & $37 \mathrm{c}$ & $46 \mathrm{ab}$ & $62 \mathrm{a}$ & $72 \mathrm{a}$ \\
P4 & 9 & $14 \mathrm{a}$ & $34 \mathrm{bc}$ & $45 \mathrm{ab}$ & $63 \mathrm{a}$ & $74 \mathrm{a}$ \\
P5 & 7 & $17 \mathrm{ab}$ & $36 \mathrm{bc}$ & $41 \mathrm{a}$ & $65 \mathrm{ab}$ & $70 \mathrm{a}$ \\
\hline
\end{tabular}

Keterangan : Hari Setelah Tanam (HST) P0 adalah aplikasi Cu dengan dosis 0 ppm, P1 aplikasi Cu dosis 25 ppm, P2 aplikasi Cu dosis 50 ppm, P3 aplikasi Cu dosis 75 ppm, P4 aplikasi Cu dosis 100 ppm dan P5 aplikasi $\mathrm{Cu}$ dosis $125 \mathrm{ppm}$

\section{Serapan Cu oleh tajuk dan akar tanaman rami}

Kandungan logam tembaga $(\mathrm{Cu})$ yang terdapat di dalam tanah akan diserap oleh akar dan ditranslokasikan kebagian-bagian yang terdapat di dalam tanaman sehingga akan berpengaruh pada kandungan tembaga $(\mathrm{Cu})$ yang terdapat di dalam akar dan tajuk tanaman rami. Sesuai dengan hasil laboratorium yang didapatkan hasil dari kandungan logam tembaga $(\mathrm{Cu})$ di dalam akar dan tajuk pada tanaman rami serta nilai 
faktor translokasi yang disajikan pada Tabel 4. Serapan logam tembaga $(\mathrm{Cu})$ yang ada di dalam tanah akan terakumulasi ke dalam bagian akar dan tajuk dari tanaman rami. Organ yang paling banyak terakumulasi logam berat tembaga $(\mathrm{Cu})$ adalah akar tanaman rami hal ini sesuai dengan pernyataan dari Yoon et al. (2006) bahwa umumnya, logam berat yang diserap oleh tanaman lebih banyak terakumulasi dalam jaringan akar tanaman dibandingkan bagian lainnya. Hal tersebut mengindikasikan logamlogam berada dalam bentuk yang tersedia bagi tanaman, namun memiliki mobilitas yang terbatas untuk di translokasikan menuju bagian atas tanaman. Tingginya kandungan logam berat dalam akar diduga karena sifat logam itu sendiri yang mempunyai massa yang besar sehingga sulit untuk di translokasikan ke jaringan tanaman bagian atas kecuali bila ada energi yang tersedia untuk memindahkan logam dari akar ke daun (Palar, 2008). Penyerapan dan translokasi tembaga $(\mathrm{Cu})$ pada tanaman rami tergantung pada tingkat ketersediaan $\mathrm{Cu}$ dalam tanah dan kondisi pertumbuhan dari tanaman itu sendiri. Hasil ini menunjukan bahwa akumulasi tembaga (Cu) paling banyak terdapat pada akar. Penyerapan logam oleh tanaman ini melibatkan sel akar, jaringan xylem, translokasi, detoksifikasi (menimbun logam di dalam organ tertentu seperti buah, daun, dan akar tanaman) dan sekuestrasi pada keseluruhan tanaman (Yang et al., 2005).

Tabel 4. Serapan $\mathrm{Cu}$ oleh tanaman rami dan nilai faktor translokasi.

\begin{tabular}{cccc}
\hline Perlakuan & $\begin{array}{c}\text { Serapan Tajuk } \\
\left(\mu g \text { tanaman }^{-1}\right)\end{array}$ & $\begin{array}{c}\text { Serapan Akar } \\
\left(\mu g \text { tanaman }^{-1}\right)\end{array}$ & $\begin{array}{c}\text { Translocation Factor } \\
(\text { TF })\end{array}$ \\
\hline P0 & $0,120 \mathrm{a}$ & $0,302 \mathrm{a}$ & 0,397 \\
P1 & $0,639 \mathrm{~b}$ & $5,906 \mathrm{~b}$ & 0,108 \\
P2 & $0,888 \mathrm{bc}$ & $4,849 \mathrm{~b}$ & 0,183 \\
P3 & $1,778 \mathrm{~d}$ & $5,465 \mathrm{~b}$ & 0,325 \\
P4 & $1,214 \mathrm{c}$ & $6,849 \mathrm{bc}$ & 0,177 \\
P5 & $0,748 \mathrm{bc}$ & $9,920 \mathrm{c}$ & 0,075 \\
\hline
\end{tabular}

Keterangan: Bilangan pada kolom yang diikuti dengan huruf yang berbeda menunjukkan berbeda nyata pada uji DMRT dengan taraf 5\%. Hari Setelah Tanam (HST) pada P0 adalah aplikasi Cu dengan dosis 0 ppm, P1 adalah dosis $\mathrm{Cu} 25$ ppm, P2 adalah dosis $\mathrm{Cu} 50$ ppm, P3 adalah dosis $\mathrm{Cu} 75$ ppm, $\mathrm{P}_{4}$ adalah dosis $\mathrm{Cu} 100$ ppm, dan P5 adalah dosis Cu 125 ppm.

Pada penelitian ini serapan Cu pada akar paling besar terdapat pada P5 dengan aplikasi dosis $\mathrm{Cu}$ 125 ppm dengan akumulasi pada akar 9,920 $\mu \mathrm{g}$ tanaman $^{-1}$ yang lebih besar dibandingkan pada daun. Hal ini sesuai dengan pendapat Liu dan Xiong (2005) yang menjelaskan bahwa semakin tinggi akumulasi $\mathrm{Cu}$ dalam akar tanaman maka akan berkorelasi dengan translokasi yang buruk. Kemampuan tanaman untuk mengekstrak $\mathrm{Cu}$ bergantung pada perolehan serapan $\mathrm{Cu}$ yang diperoleh akar dari tanah.

\section{Kandungan Cu dalam tanah}

Berdasarkan dosis dari masing-masing cemaran logam tembaga $(\mathrm{Cu})$ yang diberikan ke dalam tanah membuat kandungan logam berat di dalam tanah semakin besar, dengan analisis tanah pada media awal adalah 0,13 ppm (pembulatan bilangan dari 0,129) hasil laboratorium menunjukan kadar akhir tanah yang disajikan pada Tabel 5. Kandungan logam berat tembaga $(\mathrm{Cu})$ di dalam tanah yang tersisa paling banyak terdapat pada perlakuan P4 dengan nilai 6,59 ppm pada cemaran tembaga dosis 100 ppm. Semakin tinggi konsentrasi logam berat pada tanah maka penyerapan logam berat oleh tanaman akan semakin tinggi. Menurut Indrasti et al. (2006), salah satu faktor yang mempengaruhi penyerapan logam berat ialah konsentrasi logam berat di dalam tanah, semakin tinggi konsentrasi logam maka akan semakin banyak logam yang dapat diserap tanaman. Hal ini mungkin dapat disebabkan oleh kemampuan tanaman rami dalam mengakumulasikan $\mathrm{Cu}$ yang berbeda-beda pada setiap tanaman. Menurut Palar (2008) ion-ion $\mathrm{Ca}^{2+}, \mathrm{K}^{+}$dan $\mathrm{NH}_{4}{ }^{+}$apabila terdapat dalam jumlah besar dapat mengurangi penyerapan $\mathrm{Cu}$. 
Jurnal Tanah dan Sumberdaya Lahan Vol 7 No 2 : 291-297, 2020

e-ISSN:2549-9793, doi: 10.21776/ub.jts1.2020.007.2.13

Tabel 5. Kandungan Cu dalam tanah.

\begin{tabular}{cccc}
\hline Perlakuan & $\begin{array}{c}\text { Kadar Cu pada Tanah Awal } \\
\left(\mathbf{m g ~ k g}^{-1}\right)\end{array}$ & $\begin{array}{c}\text { Kadar Cu pada Tanah Akhir } \\
\left(\mathbf{m g ~ k g}^{-1}\right)\end{array}$ & $\begin{array}{c}\text { IBR } \\
(\mathbf{\%})\end{array}$ \\
\hline P0 & 0,13 & $0,19 \mathrm{a}$ & 0,0 \\
P1 & 10,13 & $3,80 \mathrm{~b}$ & 62,0 \\
P2 & 20,13 & $4,41 \mathrm{bc}$ & 78,0 \\
P3 & 30,13 & $5,76 \mathrm{de}$ & 80,7 \\
P4 & 40,13 & $6,59 \mathrm{e}$ & 83,5 \\
P5 & 50,13 & $5,41 \mathrm{~cd}$ & 89,2 \\
\hline
\end{tabular}

Keterangan: Bilangan pada kolom yang diikuti dengan huruf yang berbeda menunjukkan berbeda nyata pada uji DMRT dengan taraf 5\%. Hari Setelah Tanam (HST) pada P0 adalah aplikasi Cu dengan dosis 0 ppm, P1 adalah dosis $\mathrm{Cu} 25$ ppm, P2 adalah dosis Cu 50 ppm, P3 adalah dosis $\mathrm{Cu} 75$ ppm, P4 adalah dosis Cu 100 ppm, dan P5 adalah dosis Cu 125 ppm.

Apabila salah satu ion tersebut berada dalam jumlah besar di tanah akan menghambat serapan unsur hara mikro lainnya. Diduga pada P4 terdapat ion-ion tersebut yang dapat menghambat penyerapan $\mathrm{Cu}$ dari dalam tanah ke tanaman. Hal ini juga menyebabkan tinggi tanaman dan jumlah daun pada P4 normal sama dengan pertumbuhan tanaman rami pada perlakuan kontrol. Berdasarkan hasil sisa kandungan logam tembaga $(\mathrm{Cu})$ di dalam tanah ini didapatkan nilai Indeks Bioremediasi (IBR) dengan semakin besar dosis logam tembaga $\mathrm{Cu}$ yang diaplikasikan maka semakin besar nilai IBR yang dihasilkan. Hal ini sesuai dengan pernyataan dari Putri (2012) yang menyebutkan bahwa akan terjadi penurunan konsentrasi logam berat pada tanah setelah fitoremediasi dibandingkan sebelum fitoremediasi. Penurunan kandungan $\mathrm{Cu}$ dalam tanah mengindikasikan bahwa telah terjadi pemindahan logam dari tanah ke tumbuhan. Media tanam diuji untuk mengetahui efektivitas tanaman dalam menyerap Cu. Nilai tertinggi efektivitas tanaman rami dalam menyerap logam berat tembaga (Cu) adalah sebesar 89,2\% dengan konsentrasi 125 ppm. Berdasarkan persentase IBR tersebut, tanaman rami mampu dan efektif menurunkan kadar $\mathrm{Cu}>50 \%$. Hasil ini menunjukkan bahwa tanaman rami memiliki kemampuan menyerap logam berat tembaga $(\mathrm{Cu})$. Kandungan logam berat tembaga $(\mathrm{Cu})$ pada tanah, akar dan tajuk tanaman terdapat perbedaan jumlah $\mathrm{Cu}$ yang tidak sesuai dengan dosis yang sudah di aplikasikan. Hal ini dapat memungkinkan terjadinya aktivitas pencucian (leaching) atau lepasnya logam berat dari tanah yang terbawa oleh air. Menurut Palar (2008) menjelaskan bahwa selain sebagai media tumbuh tanaman, tanah juga memiliki peranan yang penting dalam proses pengangkutan bahan-bahan pencemar yang ada di dalam tanah, proses pengangkutan itu sendiri dibagi menjadi tiga yakni pengaliran (flow on), peresapan (absorption) dan pelumeran (leaching). Analisis lain yang mungkin terjadi adalah adanya ikatan antara senyawa organik dengan ion logam yang terkoordinasi. Ikatan antara senyawa organik khususnya berupa asam-asam humat dan fulvat dengan logam yang disebut sebagai kelasi atau khelat. Menurut Suci (2003) menyatakan bahwa adanya senyawa organik yang cukup memungkinkan terjadinya khelat yang berikatan dengan kation logam seperti tembaga (Cu), unsur $\mathrm{Cu}^{2+}$ terikat lebih kuat pada senyawa organik dibandingkan unsur mikro lainnya seperti Zn, Mn dan logam-logam lainnya, ikatan ini dapat mengurangi ketersediaan tembaga $(\mathrm{Cu})$ di dalam tanah, khususnya ketersediaan bagi tanaman. Kedua pernyataan tersebut memungkinkan dugaan yang terjadi akibat kandungan logam akhir yang tidak sesuai dengan dosis yang sudah diaplikasikan. Apabila kedua dugaan benar-benar terjadi maka hasil dari perhitungan Indeks Bioremediasi (IBR) tidak menunjukan hasil yang riil serapan logam tembaga oleh tanaman rami, namun dipengaruhi oleh beberapa faktor lain.

\section{Kesimpulan}

Tanaman rami dapat menurunkan akumulasi logam tembaga pada tanah sampai > 50\% dengan nilai IBR paling besar 89,2\%, dengan serapan akar paling besar pada P5 sebesar 9,920 
$\mu g$ tanaman $^{-1}$ dan serapan pada tajuk paling besar pada P3 sebesar 1,778 $\mu \mathrm{g}$ tanaman $^{-1}$. Mekanisme fitoremediasi dikategorikan dalam mekanisme fitostabilisasi karena hasil dari semua perlakuan menunjukan nilai Faktor Translokasi TF $<1$. Pada aplikasi bahan pencemar logam berat $\mathrm{Cu}$ dengan dosis 10 - 50 ppm untuk tanaman rami memberikan pengaruh nyata terhadap tinggi tanaman dan jumlah daun.

\section{Ucapan Terima Kasih}

Penulis mengucapkan terima kasih kepada Pimpinan Sekolah Tinggi Penyuluhan Pertanian (STPP) Malang atas perkenan penggunaan rumah kaca milik STPP untuk pelaksanaan penelitian ini.

\section{Daftar Pustaka}

Abror, M., Sabrina, T. dan Hidayat, B. 2013. Pengaruh biomassa Azolla terhadap status logam berat timbal $(\mathrm{Pb})$ pada tanah. Jurnal Online Agroekoteknologi 1(3): 5 - 7 .

Amelia, R.A., Rachmadiarti, F. and Yuliani. 2008. Analysis of lead level and the growth of rice plants in rice fields in Betas Village, Kapulungan, Gempol Pasuruan. LenteraBio 4(3): 187-191.

Greipsson, S. 2011. Phytoremediation. Nature Education Knowledge 3(10) : 7 .

Handayanto, E., Nuraini, Y., Muddarisna, N., Syam, N. dan Fiqri, A. 2017. Fitoremediasi dan Phytomining Logam Berat Pencemar Tanah. Malang : UB Press. 203 halaman, ISBN 978-602432-013-3.

Hardiani. 2009. Potensi tanaman dalam mengakumulasi logam $\mathrm{CuSO}_{4}$ pada media tanah terkontaminasi limbah padat industri kertas. Jurnal BS Balai Besar Pulp dan Kertas Bandung 44(1): $27-40$.
Indrasti, N.S., Suprihatin, B. dan Novita, A. 2006. Penyerapan logam $\mathrm{Pb}$ dan $\mathrm{Cd}$ oleh eceng gondok: pengaruh konsentrasi logam dan lama waktu kontak. Jurnal Teknologi Industri Pertanian 16(1): 44-50.

Liu, J. and Xiong, Z. 2005. Differences in accumulation and physiological response to copper stress in three populations of Elsholtzia baichowensis S. Water, Air and Soil Polluttion 168: 5-16.

Palar, H. 2008. Pencemaran dan Toksikologi Logam Berat. Rineka Cipta. Jakarta.

Priyanto, B. dan Prayitno, J. 2007. Fitoremediasi Sebagai Sebuah Teknologi Pemulihan Pencemaran Khususnya Logam Berat, http://ltl.bppt.tripod.com/sublab/lflora1.htm.

Putri, S. 2012. Pengolahan Air Asam Tambang Di PT. Berau Coal Lati Mine Operation. Tanjung Redeb.

Suci, H. 2003. Sifat kimia Entisol pada sistem pertanian organik. Jurnal Ilmu Pertanian 10(2): 63-69.

Sudarmaji, J., Mukono. dan Corie, 2006. Toksikologi logam berat B3 dan dampaknya terhadap kesehatan. Jurnal Kesehatan Lingkungan 2(2):129 -142.

Yang, X.E., Long, X.X., Ni, W.Z. and C.U. Fu, C.U. 2005. Sedum alfredii $\mathrm{H}$ : a new $\mathrm{Zn}$ hyperaccumulating plant first found in China. Chinese Science Bulletin 47: 1634-1637.

Yoon, J., Cao, X. and Zhou, O. 2006. Accumulation of $\mathrm{Pb}, \mathrm{Cu}$, and $\mathrm{Zn}$ in native plants growing on a contamined Florida site. Science of the Total Environment 368 : 456-464. 
halaman ini sengaja dikosongkan 